\title{
HINFI POLYMORPHISM OF THE H-FABP GENE OF DIFFERENT BREEDS OF PIGS IN THE BELGOROD REGION OF RUSSIA
}

\author{
Eduard A. Snegin ${ }^{1 *}$, Anton A. Sychev ${ }^{1}$, Olesia Yu. Artemchuk ${ }^{1}$, Anatolii S. Barkhatov ${ }^{1}$, \\ Sergei R. Yusupov ${ }^{1}$, Elena A. Snegina ${ }^{1}$, Aleksandra Yu. Tishchenko ${ }^{1}$ \\ ${ }^{1 *}$ Belgorod State University, 85, Pobedy St., Belgorod, 308015, Russia \\ *Corresponding Author Eduard A. Snegin, e-mail: snegin@ bsu.edu.ru;
}

Received August 2021; Accepted September 2021; Published October 2021;

DOI: https://doi.org/10.31407/ijees11.440

\begin{abstract}
USING the method PCR-RFLP, the pigs were genotyped for the H-FABP gene (T314C mutation). The study examined 188 boars of four breeds (Large White, Landrace, Duroc, and Yorkshire) from the Belgorod region of Russia. H-FABP3 plays a key role in fatty acid metabolism and fat deposition and is considered a candidate gene for the assessment of pig fatness and intramuscular fat (IMF) levels. Purpose of the study: Evaluation of alleles and genotype occurrence frequency for the HinfI polymorphism in the H-FABP gene among the Large White, Duroc, Landrace and Yorkshire breeds at the farms of the Belgorod region of Russia. Materials and methods: Genomic DNA was isolated from alcoholized earmarks using the DNA-Extran-2 reagent kit (SINTOL, Russia) according to the protocol. Pig genotyping for the T103C mutation was performed by PCR-RFLP method. The PCR product in the amount of $10 \mu \mathrm{l}$ was hydrolyzed with 4 units of the HinfI restriction enzyme (SibEnzyme, Russia) for 16 hours. The hydrolysis products were separated by horizontal electrophoresis in 2\% agarose gel (Mini-Sub Cell GT, BioRad, USA). Gel blocks were stained with ethidium bromide $(0.5 \mu \mathrm{g} / \mathrm{ml})$ and visualized by UV transilluminator to detect DNA fragments. Result: The highest frequency of the economically valuable allele $\mathrm{H}$ and the genotype $\mathrm{HH}$ was noted for the Yorkshire breed (0.968 and 0.94, respectively), and the smallest frequencies - for the Large White breed ( 0.628 and 0.36 , respectively). Based on the $\chi^{2}$ test, all examined breeds are in a status of genetic equilibrium based on Hardy-Weinberg. They revealed the dependence of H-FABP alleles and genotype frequencies on the T3469C polymorphism of the leptin gene (LEP). In particular, they revealed the tendency to $\mathrm{C}$ allele frequency increase for T3469C (LEP) with $\mathrm{H}$ allele frequency decrease of the H-FABP gene $(r=-0.81 \pm 0.41)$. Besides, a positive correlation was found between the frequencies of homozygous genotypes TT (LEP) and HH (H-FABP) $(r=$ $0.87 \pm 0.35)$, as well as heterozygous genotypes CT (LEP) and Hh (H-FABP) $(r=0.93 \pm 0.26)$. Conclusion: The highest frequency of the economically valuable $\mathrm{H}$ allele and the $\mathrm{HH}$ genotype were noted for the Yorkshire breed, and the lowest - for the Large White breed. They determined the originality of the gene pool of the main breeds of pigs in the Belgorod region for the polymorphism H-FABP T314C, caused by the peculiarities of local selection and crossing systems thorough the producing meat products. They revealed the dependence of alleles and genotype frequencies in the FABP and LEP genes.
\end{abstract}

Keywords: pigs, H-FABP gene, T314C mutation 